\title{
What I really want from this course is...: Tailoring Learning to Meet Students' Needs, using Pedagogies of Connection and Engagement
}

\author{
Sherilyn Lennon $1, *$

\section{Dr Sherilyn Lennon}

is Lecturer in English Education in the School of Education and Professional Studies at Griffith University in Queensland, Australia. Prior to her 2014 appointment at the University, Sherilyn worked as a Senior English Teacher, Head of Department and Literacy Project Officer in a small rural bigh school in Western Queensland. Currently, she juggles her time between University life and the family farma sheep, cattle and wheat property out West. Sherilyn is a passionate educator whose various roles and life experiences have allowed her to develop a wide and deep knowledge of issues relating to pedagogical innovation, boys' education, rurality and literacy. Her recent book, Unsettling Research (2015), examines what is possible when an educator makes use of critical and public pedagogies and media literacies to address issues relating to gender inequity and power asymmetries using a whole of community focus.

Queensland, Australia

\section{Abstract}

A problematic shift in culture has seen the focus of Western universities move from the collective pursuit of wisdom to a pre-packaging of professional knowledge and an emphasis on profits, accountability and student throughput (Connell, The good university. Paper presented at the meeting of the NTEU, Griffith University, Brisbane, Australia, 2015). This commodification of education can manifest in classrooms as reductive pedagogies of uniformity, conformity and knowledge transmission which impact on student satisfaction, attendance and teacher/student rapport. This chapter documents my attempts at resisting these pedagogies in an undergraduate Secondary English curriculum course. I set about building rapport with students by fostering democratic spaces where all were permitted a voice in designing the learning agenda. Students were encouraged to lead discussions, suggest tutorial content/foci and emotionally "check in" with their tutor. Student feedback and increased attendance rates indicate that there is value to be had in listening authentically before the talking begins.

AQ1

\section{Keywords}

\author{
Pedagogies of connection \\ Pedagogies of engagement \\ Democratic teaching \\ Teacher education \\ Educational rapport \\ Higher education pedagogies
}

\section{Introduction}

In 2013, my world changed dramatically. At that time I made a life-changing decision to leave the rural community and high school in which I had spent my entire working life as a teacher and move to the city, to take up a position as an academic in the education school of a large multi-campus Australian university located in South-east Queensland. My move from a secondary school setting with an enrolment of just under 500 students to a university setting catering for well over 40,000 students made for some steep and deep learning. Positioned precariously as both insider and outsider in my new professional life, I was forced to think deeply and critically about what should inform and influence my teaching beliefs and practices in this new educational setting. What could I bring with me from my past and what might Ineed to rethink? Ilearned early that one of the more pressing challenges facing my university colleagues and me was how to fill our 
llecture theatres and tutorial rooms with students and keep them interested, enthused and attending for the duration of our courses. In the high school setting this had not been an issue. Here I had smugly performed my role as an English teacher, content in the knowledge that my audience was captive-a direct consequence of state legislation making attendance for all students under the age of 16 years compulsory (this legislation has its own issues but that is a discussion for another time and place). The following chapter explores my use of pedagogies of engagement and connection in a university setting in order to foster democratic spaces, build tutor/student rapport and, ultimately, stem the flow of students out of the lecture halls.

\section{Transitioning as an Educator: Informants and Influences}

I began my teaching career in the mid-1980s after being posted by the state's education department to a small rural community in outback Queensland. Here I stayed for the next 28 years becoming an English teacher. In my early days/months/years I observed - with considerable envy - the convivial and generative relationships that many of my more experienced colleagues had with their students. Most memorable of all was the school's art teacher. She was about 10 years older than me, and her students would willingly spend their lunch breaks, after school hours and even weekends, toiling away on their art projects with her hovering ubiquitously beside them. At the back of the room, the latest chart topper would be blaring from a set of old speakers. She was (and still is) an inspiration to her students and her colleagues alike and it is from her that I learned a great deal about the value of building rapport with students. Rapport is defined by Frisby and Martin (2010) as "an overall feeling... encompassing a mutual, trusting, and prosocial bond" and something that students claim to be "an essential characteristic of an effective teacher" (p.146). It appeared to me that the art teacher and her students had developed such rapport. This had been nurtured by the teacher through her active listening to her students (and their music) and her inclusion of her students in decision-making about their learning/work.

$\mathbb{A Q 2}$

But it is not just my colleagues who have helped to shape, reshape, challenge and inform my teaching over many years. Also influencing my professional beliefs and practices over time have been Freirean philosophy (Freire 1971 , 1985, 2000); developments in Critical Pedagogy (see Giroux 1992, 2001, 2003; McLaren 2015 ); post-structural feminism (see Butler 1990, 2004; Davies 2005; Lather 1988, 1991 ); and the Productive Pedagogies framework, developed by a group of Queensland academics to assist teachers to reflect critically on their practice (see Lingard et al. 2000; Lingard and Mills 2003). Freire encouraged dialectical teaching and inquiry processes incorporating reflective dialogue and critical co-investigation for humanising and emancipatory purposes. Critical Pedagogy encouraged me to see my professional identity, knowledge and teaching practices as problematic, tenuous and subject to political, historical, cultural and social influences. Post-structural feminism alerted me to the need to look for, listen to and value the voices of others. The Productive Pedagogies foregrounded for me the importance of creating learning environments underpinned by intellectual rigour, a connection to students' lifeworlds and the principles of social justice and inclusion. In attempting to conceptually articulate and bundle these influences together, I would say that I lean towards post-foundational understandings of educational theorising/practice as contingent, complex, contextual and shifting (Carr 2006). This means that I am forever in a state of becoming as an educator. There is always more to leam, rethink, do and redo.

Aclnowledging the influence of Schwab (1969), Carr and Kemmis (1986) encourage a notion of "teachers as researchers" (p.18) and, in doing so, posit a critical tradition whereby educators work individually and collaboratively to critique their practice and curricula. They claim that one aspect of this approach involves educators examining:

[the] specifics of interaction between teachers and students. Micro-analyses of these interactions have proved to be extremely revealing, not only about learning outcomes, but also about the consequences of different kinds of learning opportunities and learning processes. (Carr and Kemmis 1986, p.22)

Although the focus of the Carr and Kemmis work is on teachers in schools, I contend that their strategic and critically reflexive approach is able to be adopted and adapted for the university setting.

\section{An Unsettling Moment and a Rationale for Action}


In the School of Education at my university, students were actively encouraged to attend all face-to-face teaching sessions but mandates or legislation policing for this were noticeably absent. I remember feeling unsettled after a conversation I had with a more senior colleague in the first few weeks of my academic career. My colleague had generously volunteered to show me how to limit enrolment numbers for my tutorial groups in the Junior Secondary English curriculum course that I had been assigned to convene. Both of us were bunkered down over a computer when the conversation went something like this:

Colleague: What size tutorials do you want for your course?

Me:

Hmmm, I would rather keep them at 25 or under. I find anything over that number a bit problematic when you're trying to do group work or hands-on activities.

Colleague: In that case I suggest you cap your tutorials at around 40.

Me: (Internal voice: Did she hear what I just said?) But that would make the tutorial groups huge.

Colleague: (laughing) Only for the first week. You'll be lucky to get 25 students a week after that.

When I questioned her further, I learned that increasingly poor student attendance at face-to-face lectures and tutorials was being attributed to a creeping colonisation of traditional teaching spaces by asynchronous digital learning environments. Although tutorials were not offered online, in recent years, academics at the university had been encouraged to make their lectures available online immediately after delivery. The rationale behind this request was that it provided a flexible learning environment for students whereby they had control over where and when they would study. Most face-to-face courses in the Education school were now supported by accompanying online environments. These interactive digital spaces allowed students to download course materials such as lectures, lecture notes, readings, course announcements, assessment tasks and results and participate in online discussions with others involved in the course. My colleague believed that these digital interfaces were responsible for a noticeable and ongoing decline in on-campus student attendance at the university. Massingham and Herrington (2006) have credited technology, along with changing student demographics, for declining rates of on-campus student attendance. They attribute such things as increasing numbers of mature age students, more students in paid employment, shifts in students' purposes for learning, the use of outdated teacher-centred knowledge transmission delivery models (aka "the lecture"), assessment practices that rely on recall only, and the online availability of course materials for decreasing student attendance rates at face-to-face lectures and tutorials. I know it was not uncommon for me to receive emails from students just before, or sometimes after, my lectures and tutorials with apologetic refrains along the lines of, "Sorry I am unable to attend this week's lecture/tutorial as I am juggling another life as a parent/carer/volunteer/athlete/worker/patient".

The Junior Secondary English curriculum course I convened combined both postgraduate and final year undergraduate students for a total enrolment of 84 students across two campuses. The undergraduate and postgraduate students shared a combined lecture but were separated for tutorials. The teaching period for the course ran over 9 weeks in the first half of the university calendar year. The course was comprised of 1. weekly 2-hour lecture for the first 6 weeks and 1 weekly 2-hour tutorial for 9 weeks. This arrangement meant that, for the first 6 weeks, all students were timetabled for 4 hours of face-to-face contact with me. Once the course was completed, most of the students would enrol in the following semester's Senior Secondary English curriculum course which was structured similarly and which I also convened. Both Junior and Senior Secondary English courses had accompanying online environments where students could view announcements, course outlines, timelines, lecture notes, live recordings and other resources related to the courses. The lectures were designed to introduce key concepts, frameworks and theories associated with the teaching of high school English to students. The follow-up weekly tutorials were aimed at deepening understandings of the ideas/content covered during the lectures through an exploration of English classroom pedagogies, resources, practices and curricula documents. Whilst students could access recordings of the course lectures and their accompanying notes online, the tutorials were not made available in this way.

I made it clear to students in the first lecture of these courses that there was an expectation for them to attend all tutorials. I explained that I would be keeping a tutorial attendance roll for the dual purposes of confirming course enrolment data and as a way of monitoring student engagement. Whilst this roll had no bearing on students' overall grades, I had been advised to keep it as a running record of students' investment in the course by one of my more senior colleagues. I was quite taken aback when the undergraduate students' 
tutorial attendance rate for the Junior Secondary English curriculum course had declined to $67 \%$ overall for the first 6 weeks of the course. This differed significantly from the postgraduate students' tutorial attendance rate for the correlating period which was a much healthier $82 \%$. Despite my colleague's prior warnings, I couldn't help but take the declining attendance rates of the undergraduate students as an affront; a sign that a significant proportion of them were not relating to me and/or not engaging with the course materials. In thinking this way, it would appear that I am in good company. Palmer (cited in Johnson and Reed 2012) confesses that, "my sense of self is so deeply dependent on others that I will always suffer a bit when others refuse to relate to me" (p.266). Whilst I realised that the metaphorical horse might already have bolted for semester one, I made a conscious and strategic decision to focus on using pedagogies of engagement and connection for the Senior Secondary English curriculum undergraduate course coming up in semester two. My hope was that this would build teacher/student rapport, increase student participation and address declining attendance rates.

The decision to use pedagogies of engagement and connection was informed by my previous teaching experiences and the work others have done in this area. hooks (1994) defines "engagement" as a "connection between ideas learned in university settings and those learned in life practices" (p.15). Cadman (2005) draws on hooks' insights to describe pedagogic engagement as the privileging of "opportunities for connecting -people, understandings, knowledges, feelings - in the diverse ways that a...teaching context makes possible" (Sect. 2, para. 1). In creating pedagogies of engagement, she promotes a "dynamic of connection" whereby "no two classes create the same learning environment because group priorities and patterns of interpersonal communication take different forms in each" (Sect. 4, para. 3). lembraced these understandings in addressing a number of factors. First and foremost, I wanted to improve students' experiences and performances by increasing their levels of involvement, engagement and attendance. Extended and extensive research indicates that levels of student attendance and performance are correlational (see Astin 1984; Chen and Lin 2008; Devadoss and Foltz 1996; Durden and Ellis 1995; Klem and Connell 2004). Another motivating factor was my involvement with a small group of teaching academics committed to finding new and interesting ways of understanding and improving student/teacher rapport across the School of Education. This group wanted to trial, document and share pedagogical innovations as a means of enhancing their own practices and learning from each another. Finally (and somewhat egocentrically), I was being driven to try something different by my dented sense of professional self-worth.

Approaching teaching and curriculum using a strategic view means understanding that educational practices are historically situated, that they are social activities with social consequences, that they are political acts and that they are problematic:

Under the strategic view, all aspects of an educational act may be regarded as problematic: its purpose, the social situation it models or suggests, the way it creates or constrains relationships between participants, the kind of medium in which it works, and the kind of knowledge to which it gives form. (Carr and Kemmis 1986, p.39)

I extend this claim by tendering that it is the educator as much as the practices themselves that are politically, historically and socially situated, constituted and constituting. Carr and Kemmis (1986) encourage a cycle of "systematic examination" whereby the educator "plans thoughtfully, acts deliberately, observes the consequences of action systematically, and reflects critically on the situational constraints and practical potential of the strategic action being considered" (p.40). I do not adopt understandings of these moments in the research cycle as necessarily sequential and discrete. Rather, I interpret them as overlapping, repetitious and entangled. For me, the component parts of the action research cycle yield useful methodological tools for doing what becomes knotty but strategic innovation work in educational settings. I drew on them judiciously as I set about designing, implementing and evaluating pedagogical practices to increase levels of student attendance, participation and enjoyment in my undergraduate course.

I aclnowledge that my pedagogical choices, their consequences and the subsequent contribution to knowledge that is proffered here, are idiosyncratic, situational, tentative and, quite possibly, non-transferable. However, it is in exploring the consequences of one educator's strategic and conscious decisions to use pedagogies of engagement and connection that this chapter opens up for others possibilities for renegotiating the university teaching/learning ${ }^{1}$ experience. Readers are invited to borrow from, and innovate on, the 
actions and learnings I present in this chapter as a means of reflecting on, and fostering, their own higher education pedagogies and student/teacher relationships.

\section{Planning a Pedagogical Innovation}

Although fully aware of the complexity of contextual, psychosocial, political, cultural, ideological and theoretical influences at play in any given teaching/learning moment, the intention of my small pedagogical innovation was as follows: To identify what impact I could have on a cohort of undergraduate students' engagement, participation and enjoyment levels in a second semester pre-service Senior Secondary English curriculum course as a consequence of planning thoughtfully and acting deliberately (Carr and Kemmis 1986 ). In achieving my goal, I wanted to create democratic and inclusive spaces where students would be given a voice in setting their learning agendas. To do this I needed to provide structured and dialogic opportunities in which students could meaningfully contribute to course content, direction and design. I also needed to find ways of connecting with students that would create "a mutual, trusting, and prosocial bond" (Frisby and Martin 2010, p.146).

I drew on Freirean philosophy (2000) and strategic thinking influenced by action research in education (see Carr and Kemmis 1986), as I set out on my quest to design pedagogies and practices that would increase students' participation, contributions, engagement and attendance for the semester two Senior Secondary English curriculum course. I knew I needed to act flexibly and responsively in order to avoid pre-packaged approaches to content delivery based on my personal assumptions about what students needed to know. This would mean listening to students in order to hear how they were feeling about the course and what it was that they might want to learn, rather than automatically presuming I lnew best. Parker (in Johnson and Reed 2012) argues that when "we separate teaching from learning.... [the result is] teachers who talk but do not listen and students who listen but do not talk" (p.261). He urges teachers to listen and engage authentically with their students. In doing so, he recommends the use of "dialogue as a pedagogical tool" (p.257) whereby teachers can negotiate the learning experience with and through their students. In this way, classrooms become democratised spaces that move away from the idea of teaching as an act of knowledge transmission whereby students are positioned as "containers" or "receptacles" (Freire 2000,p.67), waiting to be filled by their all-knowing, all-seeing teachers. Freire (2000) argues that by "projecting an absolute ignorance onto others, a characteristic of the ideology of oppression...education and lnowledge [are negated] as processes of inquiry" (p.68).

Evidence of the success or otherwise of my small pedagogical innovation would be measured using three datasets. I kept a weekly attendance roll which allowed me to monitor any increase or decrease in students' tutorial attendance rates throughout the semester. I mined anonymous and voluntary online Student Evaluation of Course/Teacher (SET/SEC) surveys disseminated at the conclusion of all courses by the university and I designed a pictorial survey tool that tracked students' feelings towards the course and/or their evolving needs. As students enrolling in the second semester Senior Secondary English curriculum course consisted mostly of those who had enrolled in the first semester Junior Secondary English curriculum course, I secretly wondered if this would make reversing the steadily declining tutorial attendance rates even more challenging. If students had already voted with their feet, was it possible to turn the tide?

\section{What Happens When Listening Comes First?}

In designing the first 2-hour tutorial I critically reflected (Carr and Kemmis 1986) on what had worked well from the previous year and tried to understand why. In the break between the semesters one and two courses, students regularly completed a 6-week practicum experience in schools. In the previous year I had begun the first tutorial session of the second semester by asking students to share their practicum experiences. I had initially allocated about 10 minutes for this collaborative sharing and reflection activity. At the time I had not anticipated how responsive and engaged the students would be when given an opportunity to share their stories - good and bad-and hear the stories of others. The opportunity to collaboratively share and reflect wove a rich, diverse and up-to-the-minute tapestry of what was happening in schools. Remembering how much we had all learned from each other's experiences, I decided to allow considerably more time for students to share and reflect on their practicum experiences this year. Freire (2000) supports this approach, advocating for teaching environments in which teacher and student are equal partners in learning and reflecting: 
Education takes place when there are two learners who occupy somewhat different spaces in an ongoing dialogue. But both participants bring knowledge to the relationship and one of the objects of the pedagogic process is to explore what each knows and what they can teach each other. A second object is to foster reflection on the self as actor in the world in consequence of knowing. (p.8)

I understood that handing the floor over to the students in the very first tutorial would establish me immediately as a listener and learner and thus work to democratise the teaching/learning space. Again this year students were highly engaged in the activity and I was deeply impressed by their willingness to share and reflect on their failures and successes and their responsiveness and sensitivity to the practicum stories of others. As I moved from one tutorial group to the next repeating the activity, I was amazed at how much I was learning from my students, about my students and about what was happening in English classrooms across the state.

The following week I asked students to respond to the question, "What do I want to get out of this course?" I explained that the tutorials were "up for grabs" and would be "guided by the responses I receive today". Again, students were very keen to conwibute ideas. They wanted to understand more about differentiation in English classrooms; how to deconstruct classic literary texts; techniques for making "the literary canon" relevant to high school students; how to design rigorous assessment tasks; how to incorporate technology into English classrooms; how to juggle the tensions between curriculum requirements and students' needs; teaching strategies that can be used in English classrooms; and the possibility of developing a shared online space for "dumping" useful professional resources being generated as part of their practicum requirements. Again I found students' responses reassuring. I had been concerned that, in asking students what they wanted, I might be put in a position of needing to completely redesign the course materials and subsequent tutorials. However, much of what they were requesting had been incorporated into the course in the preceding year. The difference was that I was now able to explicitly state at the beginning of each tutorial, "Today we will be focusing on-(concept/practice/document) as suggested by-(students' name[s])". The process I was using made it explicit to students that they were responsible for directing and shaping the learning. A student-centred approach to learning is considered key to creating a supportive classroom environment (Lingard et al. 2000; Lingard and Mills 2003).

Evidence that students appreciated having opportunities to direct their learning can be found in the following student responses retrieved from the university surveys (SETs and SECs):

1. We were asked what we would like to be included in the course and were catered for perfectly

2. Sherilyn listened to what we wanted out of the course and tailored her approach to the tutorials based on those answers. She also evaluated where we were at every few weeks

3. [She] asked the students what they wanted to learn and based tutes around that

4. Open to ideas and input from us

5. ...constantly asking for student input so that the learning experiences are tailored to what is going on in schools "now".

The tool I developed so that I could quickly "check in" with students to ascertain how they were feeling about their learning at key junctures throughout the 9-week course took the form of a simple emoticon survey. It consisted of an envelope-sized slip of paper with nine facial expressions on it, each one representing a different emotional state. Students were asked to circle the emoticon that best describes how you are currently feeling about this course. Underneath these emoticons was a space where students could expand on why they had made that choice.

The first time I distributed the emoticon survey was at the end of the 2-week tutorial; the second time was after the first piece of assessment - a group microteaching task - had been completed. My intention in using the survey was to see if I could trace shifts in students' feelings and understand what might be driving these. 
This knowledge could be used as either a "warning bell" or affirmation that what we were covering/doing in the lectures and tutorials was or was not meeting students' needs. The anonymous survey took students 5 minutes to complete but it was invaluable in permitting me to continue tailoring the course. Most reassuring was that the majority of students circled emoticons representing satisfaction with, joy or even passion for the course. However, some of them circled emoticons that looked worried or confused. The comments that students included on their emoticon surveys allowed me to continue evaluating my own practice, connect with students' feelings and concerns, and shepherd future tutorial directions. Sample comments included:

1. Feeling happy and excited about teaching but slightly worried about assessments to come

2. The course has been engaging and inspiring. I feel as if I am building a useful bank of relevant knowledge

3. It's all a bit overwhelming. I am engaged in the class yet I find some points hard to translate without practical experience

4. Would like some more info on the assignment

5. You are very interesting and engaging... You clearly explain the concepts...you are organized and have provided so many resources...I thoroughly enjoy your course

6. After second guessing if I was doing things the right way last semester I feel I'm now grasping relating concepts. This is reassuring after beginning study again after 18 years.

Unlike the SET and SEC surveys, which were collated and received at the completion of courses, the emoticon survey tool provided valuable interim data. It was also tangible proof to students that their opinions/feelings mattered.

Using pedagogies of engagement and connection meant that I continued to learn with and from my students. The emoticon surveys and dialogic spaces unearthed requests for things that I had not previously considered incorporating into the course. Acting on these new ideas worked to enrich the learning and relevancy of the course for all of us, as can be evidenced in the following survey feedback:

1. Real-life and relevant content! We were always given amazing resources and strategies that we could use as teachers. We were always provided with real-life examples. Everything in this course seemed so relevant and applicable to the real world unlike many other courses!

2. This course contained very relevant, interesting and engaging material.

\section{The Risks of Listening}

The words "engaging", "relevant" and "interesting" appeared many times in the student feedback. However, one survey comment troubled me:

1. A lot of content from previous semester was repeated.

Although the two consecutive Secondary English curriculum courses were designed to build on one another, there are always going to be risks associated with asking students to co-design and contribute to their learning. Before trialling these initiatives, I found myself asking: What if students don't know what they don't know? What if they fall back on knowledge that is familiar to them and want more of the same? How will I manage the tension between covering what students think they want to know and what they might not yet know that they need to know? What happens if some students want certain things and others don't? In even asking these questions am I making an assumption that I know what it is necessary to know? Am I privileging my own knowledge and devaluing students' knowledge? Leaming to let go and trust students' instincts was difficult but, I believe, worthwhile. This was reinforced for me in a student email I received 
about 3 months after the completion of the course. The student was writing to let me know that she had been offered her first teaching position:

I just want to say a heartfelt thank you for all your ideas and advice in English this year; all my supervising teachers commented on the quality and variety of my lesson activities and my knowledge of the English curriculum, both of which I attribute to your lectures and tutorials. (Personal communication, December 1, 2015)

An3

Her words reassured me that the breadth and depth of knowledge that is possible when students are encouraged to hijack the learning agenda is not compromised. Her "heartfelt thank you" signifies to me that the pedagogies of connection and engagement I employed throughout the course hit their mark.

Despite some concerns, data collected throughout this small pedagogical experiment would appear to support the benefits of using pedagogies of connection and engagement as a means of fostering democratic spaces, enriching tutor/student rapport and improving attendance. By the 6-week mark, the overall attendance rates for undergraduate students enrolled in the Senior Secondary English curriculum course had increased by over $13 \%$ (to $80.3 \%$ ) from the previous semester's course (interestingly, the postgraduate attendance rates had remained static). However, perhaps the most convincing argument for using these sorts of pedagogies in higher education settings comes from the students themselves:

Sherilyn's classes were really enjoyable to attend, as she demonstrated the power a teacher can have. Her passion for English transformed me and made me realise just how important it is to show your students how much you love your subjects. We all have favourite high school teachers that stay with us... Sherilyn has become this for me. She was my favourite lecturer and her teaching style and manner will stay with me.

This response shows how far reaching and impactful the deliberate and strategic use of different ways of negotiating learning might be. In working to create a dialogic, democratic, responsive and connected learning space, it appears that students have not only been engaged, but possibly "transformed". In this student's feedback, there is a hint that the pedagogies of engagement and connection I so consciously and strategically worked to embed in the Senior Secondary English curriculum course may well manifest in the student's future practices and classrooms.

\section{Concluding Thoughts}

This small pedagogical experiment suggests that there is merit for educators in using pedagogies of engagement and connection with their students. Such pedagogies help to generate democratic spaces where knowledge is produced collectively and learning is enjoyable, relevant and responsive. Whilst asking students to explicitly consider what they already know and what they would like to know carries risks, so too does assuming that teacher knows best. This latter attitude risks the creation of coursework that is prepackaged, preordained and delimiting. As such, it works to perpetuate pedagogies of oppression and exclusion that dilute and derail learning opportunities for all. In resisting such pedagogies and seeding democratic, dialogic and undiscovered spaces, educators need to be adventurous and trusting. The seeds we sow when we are prepared to step out of our comfort zones have the potential to be harvested and re-sewn in the lives and futures of others whom we will possibly never meet, in ways we will possibly never know. As educators surely this is both the source of our gift and our greatness:

My gift as a teacher is the ability to dance with my students, to co-create with them a context in which all of us can teach and learn, and that this gift works as long as I stay open and trusting and hopeful about who my students are. (Palmer in Johnson and Reed 2012, p.265)

\section{References}

Astin, A.W. (1984). Student involvement: A developmental theory for higher education. Journal of College Student Personnel, 25(4), 297-308. 
Butler, J. (1990). Gender trouble. London: Routledge.

Butler, J. (2004). Undoing gender. New York: Routledge.

Cadman, K. (2005). Towards a "pedagogy of connection" in critical research education: A REAL story. Journal of English for Academic Purposes, 4(4), 353-367.

Carr, W. (2006). Education without theory. British Journal of Educational Studies, 54(2), 136-159. doi:10.1111/j.1467-8527.2006.00344.x.

Carr, W., \& Kemmis, S. (1986). Becoming critical: Knowing through action research. Geelong: Deakin University Press.

Chen, J., \& Lin, T.-F. (2008). Class attendance and exam performance: A randomized experiment. The Journal of Economic Education, 39(3), 213-227. doi:10.3200/JECE.39.3.213-227.

Connell, R. (2015, November). The good university. Paper presented at the meeting of the NTEU, Griffith University, Brisbane, Australia.

AQdu

Davies, B. (2005). The subject of post-structuralism: A reply to Alison Jones. In C.Skelton \& B. Francis (Eds.), A feminist critique of education: 15 years of gender education (pp.96-109). London: Routledge.

Devadoss, S., \& Foltz, J. (1996). Evaluation of factors influencing student class attendance and performance. American Journal of Agricultural Economics, 78(3), 499-507.

Durden, G.C., \& Ellis, L.V. (1995). The effects of attendance on student learning in principles of economics. The American Economic Review, 85(2), 343-346.

Freire, P. (1971). Pedagogy of the oppressed (trans: Ramos M.B.,). New York: Herder \& Herder.

Freire, P. (1985). The politics of education. Basingstoke: Macmillan.

Freire, P. (2000). Pedagogy of the oppressed. In A. Freire \& D. Macedo (Eds.), The Paulo Freire reader (pp.45-79). New York: Continuum International.

Freire, A., \& Macedo, D. (2000). An introduction. In A. Friere \& D. Macedo (Eds.), The Paulo Freire reader (pp.4-44). New York: Continuum International.

AQ5

Frisby, B.N., \& Martin, M.M. (2010). Instructor-student and student-student rapport in the classroom.

Communication Education, 59(2), 146-164. doi:10.1080/03634520903564362.

Giroux, H. (2003). Critical theory and educational practice. In A. Darder, M.Baltodano, \& R. Torres (Eds.), The critical pedagogy reader (pp.27-56). New York: Routledge.

Giroux, H.A. (1992). Border crossings: Cultural workers and the politics of education. New York: Psychology Press.

Giroux, H.A. (2001). Theory and resistance in education: Towards a pedagogy for the opposition. Westport: Greenwood Publishing Group.

hooks, bell. (1994). Teaching to transgress: Education as the practice of freedom. London: Routledge.

Johnson, T., \& Reed, R. (2012). Philosophical documents in education (4th ed). New Jerscy: Pearson 
Education.

Klem, A.M., \& Connell, J.P. (2004). Relationships matter: Linking teacher support to student engagement and achievement. Journal of School Health, 74(7), 262-273.

Lather, P. (1988). Feminist perspectives on empowering research methodologies. Women's Studies International Forum, 11(6), 569-581.

Lather, P. (1991). Feminist research in education: Within/Against. Geelong: Deakin University.

Lingard, B., \& Mills, M. (2003). Teachers and school reform: Working with productive pedagogies and productive assessment. Critical Studies in Education, 44(2), 1-18.

Lingard, B., Mills, M., \& Hayes, D. (2000). Teachers, school reform and social justice: Challenging research and practice. The Australian Educational Researcher, 27(3), 101-115.

Massingham, P., \& Herrington, T. (2006). Does attendance matter? An examination of student attitudes, participation, performance and attendance. Journal of University Teaching \& Learning Practice, 3(2), 82103.

McLaren, P. (2015). Life in schools: An introduction to critical pedagogy in the foundations of education (6th ed). Boulder: Paradigm.

Schwab, J.J. (1969). The practical: A language for curriculum. The School Review, 78(1), 1-23.

${ }^{1}$ Teaching/learning is not intended as a binary whereby the teacher teaches and the student learns. As can be evidenced from this chapter -and indeed the book-committed educators are forever learning. 